\title{
Genome-wide association study for ketosis in US Jerseys using producer-recorded data
}

\author{
K. L. Parker Gaddis, ${ }^{* 1}$ J. H. Megonigal Jr., ${ }^{*}$ J. S. Clay, $†$ and C. W. Wolfeł \\ ${ }^{*}$ Council on Dairy Cattle Breeding, Bowie, MD 20716 \\ †Dairy Records Management Systems, Raleigh, NC 27603 \\ $\ddagger$ American Jersey Cattle Association, Reynoldsburg, $\mathrm{OH} 43068$
}

\section{ABSTRACT}

Ketosis is one of the most frequently reported metabolic health events in dairy herds. Several genetic analyses of ketosis in dairy cattle have been conducted; however, few have focused specifically on Jersey cattle. The objectives of this research included estimating variance components for susceptibility to ketosis and identification of genomic regions associated with ketosis in Jersey cattle. Voluntary producer-recorded health event data related to ketosis were available from Dairy Records Management Systems (Raleigh, NC). Standardization was implemented to account for the various acronyms used by producers to designate an incidence of ketosis. Events were restricted to the first reported incidence within $60 \mathrm{~d}$ after calving in first through fifth parities. After editing, there were a total of 42,233 records from 23,865 cows. A total of 1,750 genotyped animals were used for genomic analyses using 60,671 markers. Because of the binary nature of the trait, a threshold animal model was fitted using THRGIBBS1F90 (version 2.110) using only pedigree information, and genomic information was incorporated using a single-step genomic BLUP approach. Individual single nucleotide polymorphism (SNP) effects and the proportion of variance explained by 10-SNP windows were calculated using postGSf90 (version 1.38). Heritability of susceptibility to ketosis was 0.083 [standard deviation $(\mathrm{SD})=0.021]$ and $0.078(\mathrm{SD}=0.018)$ in pedigree-based and genomic analyses, respectively. The marker with the largest associated effect was located on chromosome 10 at $66.3 \mathrm{Mbp}$. The 10-SNP window explaining the largest proportion of variance $(0.70 \%)$ was located on chromosome 6 beginning at $56.1 \mathrm{Mbp}$. Gene Ontology (GO) and Medical Subject Heading (MeSH) enrichment analyses identified several overrepresented

Received June 22, 2017.

Accepted September 16, 2017.

${ }^{1}$ Corresponding author: kristen.gaddis@uscdcb.com processes and terms related to immune function. Our results indicate that there is a genetic component related to ketosis susceptibility in Jersey cattle and, as such, genetic selection for improved resistance to ketosis is feasible.

Key words: genetic parameter, genome-wide association study, Jersey, ketosis

\section{INTRODUCTION}

An unfavorable association between production and health has become clear with the significant progress made in the dairy industry for traits related to yield throughout recent decades (e.g., Pryce et al., 1998; Esposito et al., 2014). Declining health of dairy cows is an important concern for producers because it can result in decreased profitability due to increased veterinary costs, replacement rates, and labor, among other factors. Concurrently, the public increasingly wants assurances that the dairy products they consume are from healthy animals raised in a humane environment (Boichard and Brochard, 2012).

Metabolic diseases are common among high-producing dairy cows, especially in early lactation (Pryce et al., 2016). At that time, the cow is transitioning from a pregnant, nonlactating state through parturition to lactation. During this period, the cow typically enters a state of negative energy balance, in which it is unable to consume enough energy to wholly support the requirements of lactation, and must rely on stored body reserves. One metabolic disease that can arise during this period is ketosis, which is one of the most important metabolic diseases in US dairy herds (Oetzel, 2007). Total cost per incidence is estimated to be $\$ 77$ in first parity and $\$ 181$ in later parities (Liang et al., 2017). Costs associated with ketosis include treatment, increased risk of other diseases, risk of decreased reproductive performance, decreased milk production, and higher risk of culling in early lactation (Gordon et al., 2013). Ketosis is thought to occur most often due to an imbalance in the supply and demand of glucose typical- 
ly occurring early in lactation (Baird, 1982). Symptoms can include decreased appetite, decreased milk production, weight loss, hypoglycemia, and hyperketonemia (Baird, 1982). Risk factors for ketosis include milk fever (Bigras-Poulin et al., 1990), later parity (Bigras-Poulin et al., 1990; Gröhn et al., 1984), high production (Gröhn et al., 1989), displaced abomasum (Curtis et al., 1985), and prior incidence of metritis (Dohoo and Martin, 1984). Additional risk factors include over-conditioning before parturition, season of calving, prolonged previous lactation length, extended dry period length, and amount of colostrum produced (Vanholder et al., 2015). Herds with an increased incidence of ketosis in early lactation tend to have increased incidences of displaced abomasum and increased culling in the first $60 \mathrm{~d}$ in milk (Oetzel, 2007). All of the above impacts of ketosis will have a negative effect on profitability for producers and are detrimental to animal well-being.

Incidence estimates of ketosis have been reported in several different dairy populations, though few specific to the Jersey breed. Based on 18 large-scale studies, median incidence of ketosis was 3.3\% (Pryce et al., 2016) with values ranging from $0.24 \%$ in first-parity animals (Kadarmideen et al., 2000) to $17.2 \%$ in thirdparity animals (Heringstad et al., 2005). Genetic variability, albeit small, has been identified to play a role in resistance to ketosis. Because ketosis has been shown to have a genetic component (e.g., Heringstad et al., 2005; Koeck et al., 2012; Parker Gaddis et al., 2014), one method for improving ketosis resistance would be through genetic selection. Heritability estimates for ketosis in US Holsteins range from 0.04 to 0.14 (Zwald et al., 2004; Parker Gaddis et al., 2014), although corresponding values specific to Jerseys are not available.

The objectives of this study were to estimate variance components for ketosis in Jerseys from available producer-recorded data. Given a significant genetic component, we also sought to identify regions of the genome associated with ketosis and investigate these regions for genes and biological pathways that could play a role in ketosis susceptibility in Jerseys.

\section{MATERIALS AND METHODS}

\section{Data}

Voluntary producer-recorded health event data related to ketosis were available from Dairy Records Management Systems (North Carolina State University, Raleigh) from US farms. Data editing was performed similarly to that described in Parker Gaddis et al. (2012). Standardization of ketosis codes was implemented to account for the numerous different acronyms used in herds to represent ketosis. General editing of ketosis data included selecting records from Jersey animals with an acceptable ID located within US herds. Ketosis events were restricted to occurring within $60 \mathrm{~d}$ after calving. Cows were considered healthy if they did not have a reported ketosis event within this period. If multiple ketosis events were recorded during a single lactation, only the first event was retained for analysis. Ketosis event data were merged with lactation data available from the Council on Dairy Cattle Breeding (CDCB; Bowie, MD). Only completed lactation records from cows within parities 1 through 5 were retained for analysis. We detected no significant difference in incidence rate between first-lactation and laterlactation animals. Minimum and maximum constraints on the occurrence of ketosis were implemented on a herd-year basis in an attempt to exclude information from herds that either did not report ketosis or overreported ketosis events (a possible indication of using the acronym for management of ketosis as opposed to diagnosis). As a minimum constraint, herd-years were required to have at least 5 cows with lactation records and at least 1 reported incidence. The maximum constraint required that a herd-year's incidence not be greater than 3 standard deviations beyond the overall average incidence. Pedigree information spanned 3 generations, including 49,382 animals. A summary of the data set is provided in Table 1.

Genotypes were obtained from CDCB and included the 60,671 markers used for national routine genomic evaluations in the United States. These SNP were previously selected based on criteria including minor allele frequency, parent-progeny conflicts, call rate, and correlation between SNP (Wiggans et al., 2010, 2016). A total of 1,750 genotyped animals were used for the analyses. These included cows in the data set that were genotyped as well as genotyped sires. The majority of these animals $(n=1,497)$ were genotyped with either version 1 or 2 of the Illumina BovineSNP50 BeadChip (Illumina Inc., San Diego, CA), with the remaining animals genotyped on other platforms. All animals were imputed to the common set of 60,671 markers using Findhap version 3 (VanRaden et al., 2011).

Table 1. Summary statistics

\begin{tabular}{lc}
\hline Number of records & 42,233 \\
Number of animals & 23,865 \\
Number of herd-years & 272 \\
Mean incidence of ketosis (\%) & 2.81 \\
Number of genotyped individuals & 1,750 \\
Number of SNP after editing & 60,671 \\
\hline
\end{tabular}




\section{Analysis}

Given the binary nature of the trait, a threshold animal model was fitted using THRGIBBS1F90 version 2.110 (Tsuruta and Misztal, 2006). The model specified was

$$
\boldsymbol{\lambda}=\mathbf{X} \boldsymbol{\beta}+\mathbf{Z}_{\mathrm{h}} h+\mathbf{Z}_{\mathrm{a}} a+\varepsilon,
$$

where $\boldsymbol{\lambda}$ represents a vector of unobserved liabilities to ketosis; $\boldsymbol{\beta}$ represents a vector of fixed effects including overall mean, parity, and year-season; $\mathbf{X}$ is the corresponding incidence matrix for fixed effects; $h$ represents the random herd-year effect, where $h \sim N\left(0, \mathbf{I} \sigma_{h}^{2}\right)$, with I representing an identity matrix and $\sigma_{h}^{2}$ representing the herd-year variance; $a$ represents the random animal effect, where $a \sim N\left(0, \mathbf{A} \sigma_{a}^{2}\right)$, with $\mathbf{A}$ representing the additive relationship matrix and $\sigma_{a}^{2}$ representing the additive genetic variance; $\mathbf{Z}_{\mathrm{h}}$ and $\mathbf{Z}_{\mathrm{a}}$ represent the corresponding incidence matrices for the respective random effects; and $\varepsilon$ represents the random residual, where $\varepsilon \sim N(0, \mathbf{I})$, with the variance fixed to 1 for identifiability (represented by an identity matrix I). To account for repeated records from an animal, a random permanent environment effect was initially included, but the model did not converge. Season was specified as 4 categories: winter (December, January, February), spring (March, April, May), summer (June, July, August), and fall (September, October, November). Given the data set size, differences due to parity were accounted for by a fixed effect as opposed to analyzing primiparous and multiparous animals separately. A total of 300,000 iterations were completed with the first 20,000 samples discarded as burn-in, saving every 50th sample. Post-Gibbs analyses were completed using the POSTGIBBSF90 software (version 3.06; Misztal et al., 2002). Trace plots were inspected to ensure that convergence had been reached. Estimates of variance components and their standard deviation were calculated from posterior samples.

Given that health traits in general have low heritabilities and reliabilities, genomic information provides a large benefit by decreasing the amount of time required to reach acceptable levels of reliability. Single-step genomic BLUP (ssGBLUP) methodology was used to incorporate available genomic information and conduct the genome-wide association analysis herein. Using single-step methodology allowed the incorporation of information from animals that were not genotyped but had phenotypic information. It does not require deregression procedures or the creation of "pseudo- phenotypes," which often have poor performance for traits such as health that have low heritabilities and low reliabilities. Single-step methodology is also easily expanded beyond linear models to more complex models, making it a suitable choice when analyzing a binary trait. The model was the same as that described above, with the exception of the additive relationship matrix (A) being replaced by a blended $\mathbf{H}$ matrix that incorporated both pedigree and genomic information, the inverse of which is shown below (Aguilar et al., 2011):

$$
\mathbf{H}^{-1}=\mathbf{A}^{-1}+\left[\begin{array}{cc}
0 & 0 \\
0 & \mathbf{G}^{-1}-\mathbf{A}_{22}^{-1}
\end{array}\right],
$$

where $\mathbf{A}_{22}^{-1}$ represents the inverse additive relationship matrix between genotyped individuals, and $\mathbf{G}^{-1}$ represents the inverse genomic relationship matrix between genotyped individuals. A total of 300,000 iterations were completed, saving every 25 th sample, with the first 20,000 samples discarded as burn-in. Post-Gibbs analyses were completed as described above. Genomewide association analyses were conducted with individual SNP effects as well as sliding 10-SNP windows using postGSf90 (version 1.38; Aguilar et al., 2014). Regions with the largest effects and regions explaining the largest proportions of additive variance were investigated for putative genes associated with ketosis. Results were compared with previous results from studies of related traits using CattleQTLdb (Hu et al., 2013).

Enrichment analyses were conducted to identify biological pathways and terms associated with ketosis susceptibility. Gene Ontology (GO) enrichment aims to identify biological functions that a selected group of genes shares (Ashburner et al., 2000). Medical Subject Headings (MeSH) are a collection of life sciences vocabulary taken from the keywords of publications. This vocabulary includes more than 25,000 clinical and biological annotations, and it has previously been shown to enhance enrichment analyses conducted in livestock species beyond that of GO enrichment (Morota et al., 2015). The SNP were merged with the closest gene within $25 \mathrm{~kb}$ using BEDTools version 2.26.0 (Quinlan and Hall, 2010). The genes nearest to the 500 SNP with the largest effects on ketosis were used for enrichment analyses. Gene annotation was based on the bovine UMD 3.1 genome assembly (Zimin et al., 2009), Ensembl release 87 (Yates et al., 2016). Enrichment analyses of GO terms were conducted with the GOstats package (Falcon and Gentleman, 2007) in R (version 3.3.3; R Core Team, 2017). Analyses using MeSH were conducted with the meshr package (Morota et al., 2015; 
Table 2. Variance component and heritability estimates (SD) from pedigree-based and single-step genomic BLUP (ssGBLUP) analyses

\begin{tabular}{lcc}
\hline Component & Pedigree & ssGBLUP \\
\hline Herd-year variance & $0.303(0.036)$ & $0.301(0.036)$ \\
Additive genetic variance & $0.119(0.034)$ & $0.110(0.027)$ \\
Residual variance & $1.000(0.010)$ & $1.000(0.010)$ \\
Heritability & $0.083(0.021)$ & $0.078(0.018)$ \\
\hline
\end{tabular}

Tsuyuzaki et al., 2015), also implemented in R (version 3.3.3).

\section{RESULTS AND DISCUSSION}

Variance component and heritability estimates are provided in Table 2 for both the pedigree-based analysis and ssGBLUP analysis. Estimates from the 2 analyses were very comparable and not significantly $(P$ $<0.05)$ different. As previously noted, we were unable to fit a permanent environment effect in the model. This may bias the heritability estimates; however, we found no significant difference in heritability estimates compared with a model with only first-parity records. As more ketosis records are collected, fitting a permanent environment effect should be less difficult and should be included to avoid this potential bias. The heritability estimate of approximately $8 \%$ falls within the range of previously reported heritabilities for ketosis, despite most studies not including Jerseys. Using a threshold sire model, heritabilities have been reported from 0.02 in Holsteins (Kadarmideen et al., 2000) to 0.16 in Norwegian Red (Heringstad et al., 2005). Recently, Vukasinovic et al. (2017) reported a heritability of ketosis of 0.059 using a threshold animal model from producer-recorded data on Holsteins.

Results from the association analysis of individual SNP effects are shown in Figure 1 as a Manhattan plot. Susceptibility to ketosis in Jerseys appears to be affected by numerous regions across the genome. The largest peak was identified on chromosome 10 at 66.3 Mbp. Additional peaks [absolute SNP effect/SD (SNP variance) $>5$ ] were located on chromosome 11 (12.4 Mbp; $13.1 \mathrm{Mbp}$ ), chromosome 14 (35.7 Mbp), and chromosome 23 (34.0 Mbp). The top 20 individual markers with the largest associated effects are listed in Table 3. Proportion of variance explained by $10-\mathrm{SNP}$ sliding windows is shown in Figure 2. The largest proportion of variance explained was a region located on chromosome 6 at approximately 56.1 Mbp. Additional chromosomes with regions explaining large proportions of variance include chromosome 11 (12.0 Mbp; $14.9 \mathrm{Mbp} ; 16.9$ Mbp), chromosome 3 (60.5 Mbp), and chromosome 25 (1.2 Mbp). The top 20 regions explaining the largest proportion of variance are detailed in Table 4 . An overview of putative genes located near these associated regions of the genome is provided in Table 5. Many of the genes included in Table 5 fall under at least one common broad category. For example, 6 genes were in some way involved in insulin secretion or regulation. Several genes have been cited in the literature as being

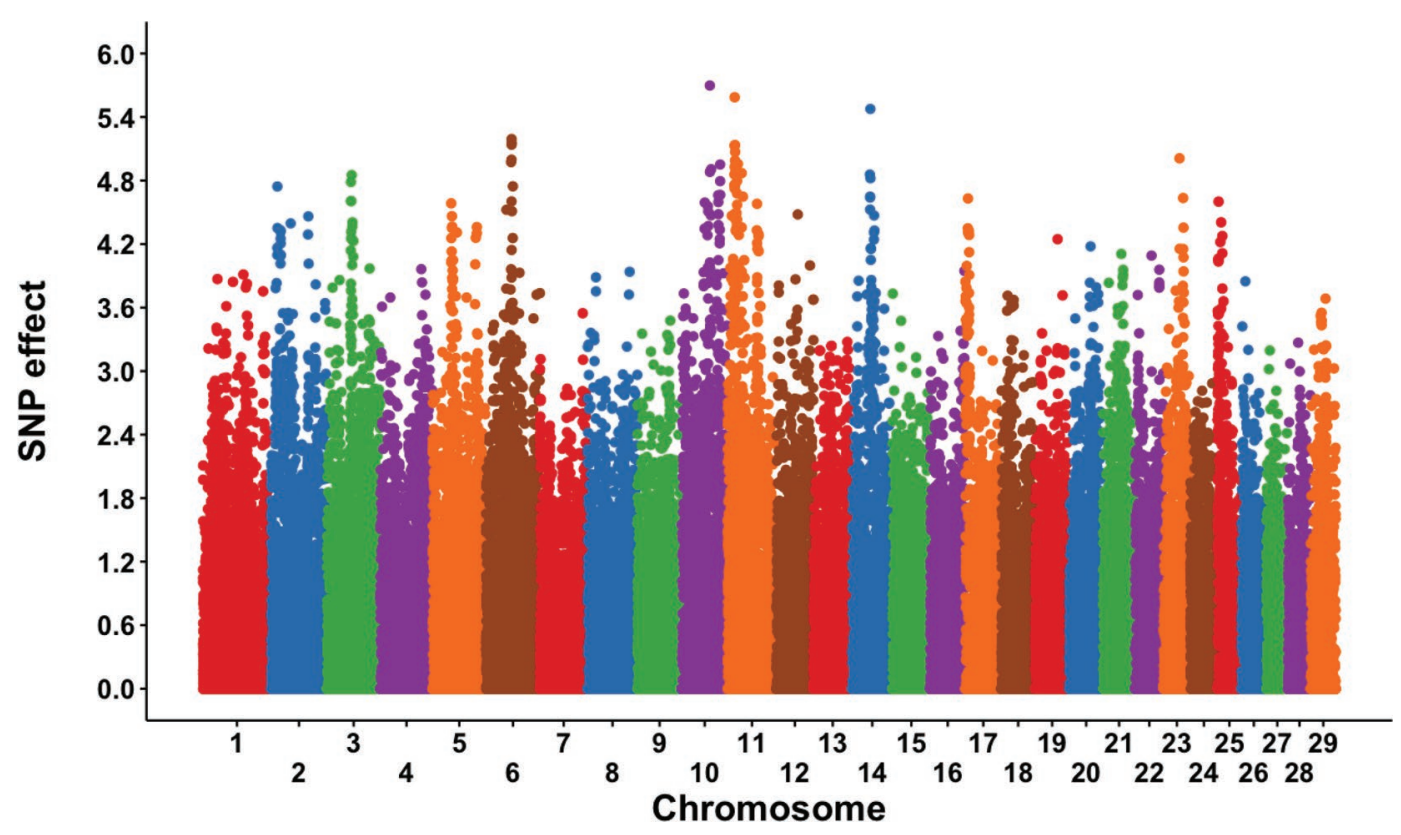

Figure 1. Manhattan plot of standardized SNP effects (absolute value of SNP effect/standard deviation of SNP variance) associated with ketosis in a single-step genomic BLUP genome-wide association analysis. Color version available online. 


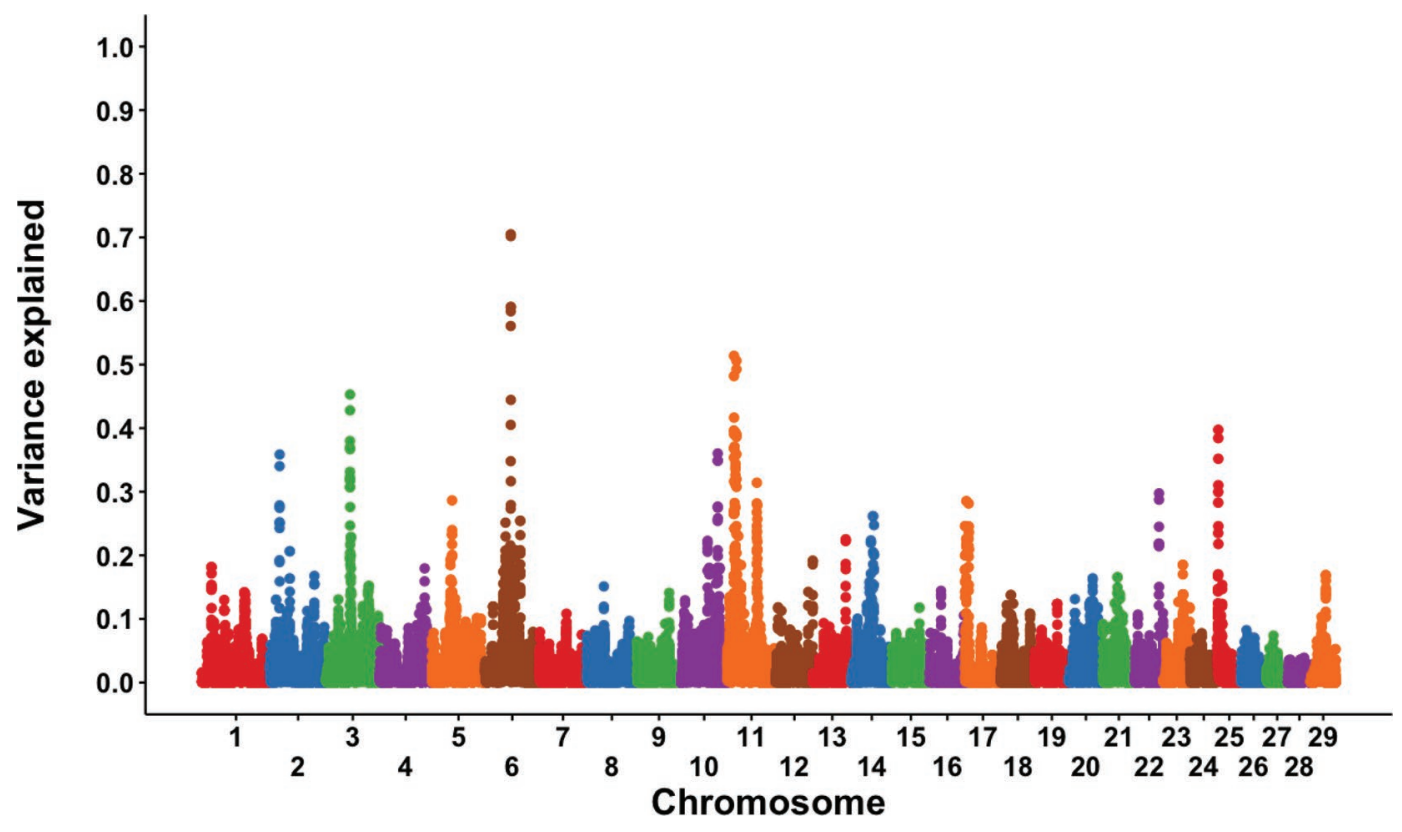

Figure 2. Proportion of additive variance explained by 10-SNP windows associated with ketosis using single-step genomic BLUP genomewide association analysis. Color version available online.

involved in the immune system, and lipid metabolism was found to be common among several of the identified genes. Each of these broad categories and their respective genes will be further discussed below.

Insulin is a key metabolic hormone (Herdt, 2000) and an indicator of energy status (Blum et al., 1983). Insulin acts in a feedback loop where nonesterified fatty acids (NEFA) and ketone bodies stimulate insulin secretion and insulin then acts to suppress the formation of more ketone bodies (Herdt, 2000). Hormonal changes during the transition period cause decreases in plasma insulin levels and reduced insulin sensitivity in adipose and peripheral tissues, among other changes (Contreras and Sordillo, 2011). Early lactating dairy cows typically have reduced blood insulin levels to support lactation. Decreased insulin concentrations lead to increased glucose uptake in the mammary gland to support the synthesis of lactose (Gross et al., 2011). Health disor-

Table 3. The 20 markers with largest individual effects (absolute value of SNP effect/standard deviation of SNP variance) for ketosis susceptibility in single-step genomic BLUP genome-wide association analysis

\begin{tabular}{llll}
\hline Marker & Chromosome & Location (bp) & Effect size \\
\hline BovineHD1000019115 & 10 & $66,294,038$ & 5.70 \\
BovineHD1100004092 & 11 & $12,421,254$ & 5.59 \\
BovineHD1400010298 & 14 & $35,737,818$ & 5.48 \\
BTB-00258418 & 6 & $56,464,060$ & 5.19 \\
Hapmap49021-BTA-111079 & 6 & $56,663,172$ & 5.16 \\
BTA-94706-no-rs & 6 & $56,345,409$ & 5.14 \\
ARS-BFGL-NGS-100878 & 11 & $12,856,120$ & 5.14 \\
BTB-00649769 & 11 & $12,088,913$ & 5.13 \\
ARS-BFGL-NGS-2493 & 11 & $13,114,243$ & 5.07 \\
ARS-BFGL-NGS-107881 & 23 & $33,961,556$ & 5.01 \\
Hapmap40151-BTA-94687 & 6 & $56,188,532$ & 5.00 \\
Hapmap48102-BTA-85468 & 11 & $12,970,800$ & 4.99 \\
BTB-01133266 & 6 & $55,213,555$ & 4.97 \\
ARS-BFGL-NGS-72469 & 11 & $18,635,979$ & 4.96 \\
ARS-BFGL-NGS-17218 & 10 & $89,905,548$ & 4.95 \\
ARS-BFGL-NGS-100255 & 11 & $12,390,287$ & 4.93 \\
BTB-01529593 & 11 & $15,092,090$ & 4.92 \\
BTB-00462019 & 11 & $15,115,350$ & 4.92 \\
BTB-01420453 & 10 & $69,287,432$ & 4.91 \\
Hapmap60320-rs29010337 & 10 & $66,560,673$ & 4.88 \\
\hline
\end{tabular}


Table 4. The 20 markers explaining the largest proportion of SNP variance for ketosis susceptibility using 10SNP sliding windows in single-step genomic BLUP genome-wide association analysis

\begin{tabular}{llcc}
\hline Marker & Chromosome & $\begin{array}{c}\text { Location } \\
(\mathrm{bp})\end{array}$ & $\begin{array}{c}\text { Variance } \\
\text { explained (\%) }\end{array}$ \\
\hline ARS-BFGL-NGS-98343 & 6 & $56,129,705$ & 0.70 \\
BTB-01133499 & 6 & $56,164,953$ & 0.70 \\
BTB-01133278 & 6 & $56,278,798$ & 0.59 \\
BovineHD0600015400 & 6 & $56,300,696$ & 0.59 \\
Hapmap40151-BTA-94687 & 6 & $56,188,532$ & 0.58 \\
BTA-00391-no-rs & 6 & $55,916,841$ & 0.56 \\
BTB-00649769 & 11 & $12,088,913$ & 0.51 \\
ARS-BFGL-NGS-3795 & 11 & $16,856,278$ & 0.51 \\
BovineHD1100005252 & 11 & $16,865,585$ & 0.49 \\
ARS-BFGL-BAC-13568 & 11 & $11,994,246$ & 0.48 \\
Hapmap55559-rs29014148 & 3 & $60,445,547$ & 0.45 \\
BTA-94706-no-rs & 6 & $56,345,409$ & 0.44 \\
BTB-01322840 & 3 & $60,502,347$ & 0.43 \\
BTB-00461346 & 11 & $12,201,969$ & 0.42 \\
BTA-94697-no-rs & 6 & $55,880,308$ & 0.41 \\
ARS-BFGL-BAC-43143 & 25 & $1,184,038$ & 0.40 \\
BTA-122291-no-rs & 11 & $11,804,294$ & 0.40 \\
BTB-00483333 & 11 & $14,927,083$ & 0.39 \\
BTA-85490-no-rs & 11 & $12,170,656$ & 0.39 \\
BTA-119408-no-rs & 11 & $16,884,532$ & 0.39 \\
\hline
\end{tabular}

ders associated with negative energy balance, such as ketosis, have been associated with an insulin-resistant state of dairy cows near parturition (Kerestes et al., 2009; Gross et al., 2011).

Genes related to insulin regulation located near associated regions of the genome included $B M P 4$, EXOC6B, ATP6V1B1, SLC30A6, RASGRP3, and $U B E 21$. The $B M P 4$ gene has recently been implicated in the development of metabolic pathologies (Grgurevic et al., 2016). Signaling of $B M P 4$, along with the BMP type 1a receptor, within $\beta$ cells has been shown to be required for insulin secretion and regulation (Goulley et al., 2007). Mice deficient in BMP 4 have been shown to have impaired insulin sensitivity, indicating that $B M P 4$ plays a role in metabolism (Qian et al., 2013). The EXOC6B gene is a component of the exocyst complex that docks insulin granules to the plasma membrane and is also involved in insulin secretion (Suriben et al., 2015). The ATP6V1B1 gene has been implicated in pathways including signaling by insulin receptors, in addition to general metabolic pathways (Geer et al., 2010). Reactome pathways involving insulin processing (R-BTA-264876; http://www.reactome.org/ content/detail/R-BTA-264876) and transport of glucose, among other compounds such as bile salts, metal ions, and other sugars (R-BTA-425366; http://www .reactome.org/content/detail/R-BTA-425366) were found for SLC30A6. The RASGRP3 gene is a member of the RAS subfamily of GTPases and has been implicated in Reactome pathways (Croft et al., 2014; Fabregat et al., 2016) including signaling by insulin receptor (R-BTA-74752; http://www.reactome.org/
content/detail/R-BTA-74752) and signaling by leptin (R-BTA-2586552; http://www.reactome.org/content/ detail/R-BTA-2586552). Leptin is a hormone made by adipose cells that acts to regulate energy balance by inhibiting hunger. Leptin has been shown to affect voluntary feed intake (Blache et al., 2000), as well as insulin resistance in periparturient ruminants (Ingvartsen and Boisclair, 2001). Finally, UBE21 is involved in many cellular processes but may also be involved in modifying insulin secretion (Dai et al., 2011).

Lipid metabolism, or the formation and breaking down of triglycerides, is closely tied to insulin regulation. Within adipose tissues, insulin stimulates lipogenesis and inhibits lipolysis. Lipolysis and lipogenesis together create a cycle of moving fatty acids, either from triglycerides to NEFA or from NEFA to triglycerides. As described above, ketone bodies and NEFA stimulate insulin secretion, which creates a feedback loop, resulting in suppressed mobilization of additional NEFA by insulin. In this way, insulin functions as a regulatory hormone of lipid metabolism (Herdt, 2000). During the transition period of dairy cows, hormonal changes cause lipolysis to be favored (Contreras and Sordillo, 2011). Negative energy balance also leads to increased mobilization of lipids (Tetens et al., 2015). Problems that arise within these processes can lead to metabolic disorders, including ketosis (Kessel et al., 2008). A link has been proposed between lipid homeostasis and leukocyte dysfunction, thereby also affecting the immune system (Contreras and Sordillo, 2011).

Genes in associated genomic regions involved in lipid metabolism included DDHD1, CYP26B1, SRD5A2, 
Table 5. Genes from selected regions of the genome with strong association with ketosis susceptibility in Jerseys

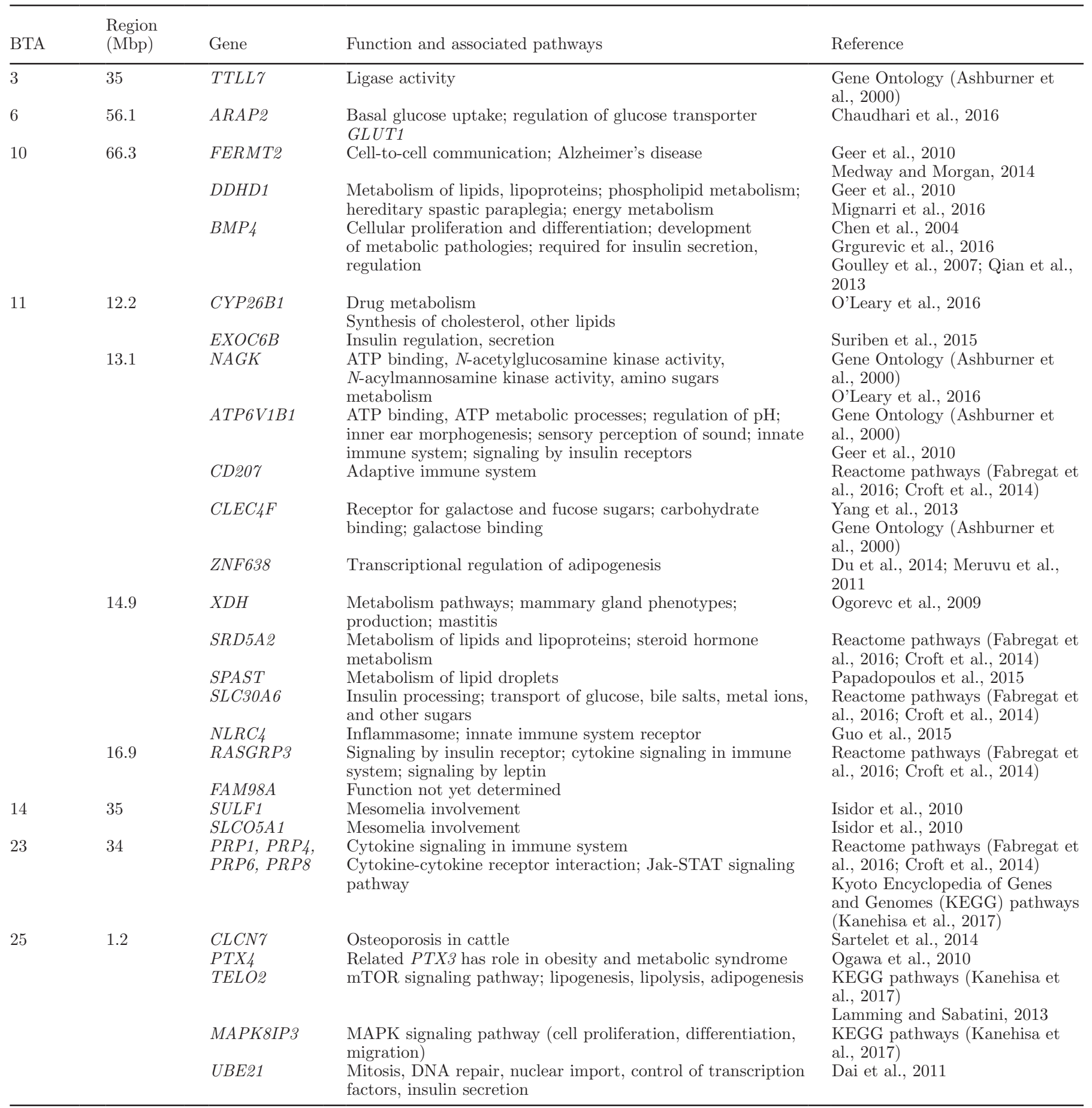

SPAST, and TELO2. The DDHD1 gene is involved in pathways including metabolism of lipids and lipoproteins and phospholipid metabolism (Geer et al., 2010). The CYP26B1 gene is part of the cytochrome $\mathrm{P} 450$ superfamily. Cytochrome $\mathrm{P} 450$ proteins catalyze many different reactions throughout the body, including drug metabolism and synthesis of cholesterol and other lipids. A similar gene, CYP11B1, located on chromosome 14, has been associated with fat:protein ratio in primiparous German Holsteins (Tetens et al., 2013). The SRD5A2 gene has been identified in Reactome pathways (Croft et al., 2014; Fabregat et al., 2016), including metabolism of lipids and lipoproteins, as well as steroid hormone metabolism (R-BTA-556833; http:// 
www.reactome.org/content/detail/R-BTA-556833). The SPAST gene has been shown to have a role in metabolism of lipid droplets (Papadopoulos et al., 2015); and TELO2 is involved in the 2 complexes making up the mammalian target of rapamycin (mTOR) signaling pathway. Complex 1 is activated by the presence of growth factors, amino acids, energy status, stress, or oxygen levels and regulates several biological processes including lipid metabolism, autophagy, and protein synthesis. The second mTOR complex responds to growth factors and controls cytoskeletal organization, metabolism, and survival (Kanehisa et al., 2017). Both mTOR complexes have been found to be involved in lipogenesis and lipolysis, as well as adipogenesis (Lamming and Sabatini, 2013).

Problems in regulating immune response have previously been proposed as a missing link in understanding metabolic disorders in transition dairy cows (Esposito et al., 2014). One known interaction occurs when a dairy cow enters a state of negative energy balance. This affects not only the metabolic processes of the animal, but also the immune and inflammatory responses (Contreras and Sordillo, 2011). One route by which this occurs involves large amounts of NEFA being released from adipose tissue when a cow is in a negative energy balance (Herdt, 2000). Elevated NEFA levels, in addition to the length of time that NEFA levels are elevated, have been shown to disrupt numerous immune and inflammatory functions (Contreras and Sordillo, 2011).

Genes involved in the immune system located close to associated regions of the genome included ATP6V1B1, CD207, NLRC4, RASGRP3, and several genes encoding prolactin-related proteins. In addition to being involved in insulin-related processes as described above, $A T$ P6V1B1 has been implicated in pathways including the innate immune system. The CD207 gene is associated with Reactome pathways (Croft et al., 2014; Fabregat et al., 2016) including the adaptive immune system (R-BTA-1280218; http://www.reactome.org/content/ detail/R-BTA-1280218). The NLRC4 gene is characterized as an inflammasome, which are innate immune system receptors and sensors that induce inflammation (Guo et al., 2015). Other inflammasomes such as IL-1 $\beta$ and IL-18 have been linked to the development of metabolic inflammation and to the progression of metabolic problems (Henao-Mejia et al., 2014). In addition to being involved in insulin-related processes, RASGRP 3 is involved in Reactome pathways, including cytokine signaling in the immune system (R-BTA-1280215; http:// www.reactome.org/content/detail/R-BTA-1280215). Additionally, we identified several genes encoding prolactin-related proteins (PRP1, PRP4, PRP6, PRP8) near a peak on chromosome 23 that are associated with cytokine signaling in the immune system. Cytokines play a key role in inflammatory responses, including increased body temperature and heart rate, as well as decreased feed intake (Dantzer and Kelley, 2007).

Specifically investigating studies conducted in cattle, no peaks identified in the present research aligned with a study that sought to identify SNP associated with subclinical ketosis in Jersey cattle (Fugate et al., 2014). This might be due to differences in susceptibility between subclinical and clinical ketosis. Given that the data used herein were on-farm producer-recorded events, it is likely that the majority of these events were clinical cases of ketosis. The peak on chromosome 6 is within a region that was previously found to be associated with the milk metabolites glucose and glutamate in a study using Danish Holsteins (Buitenhuis et al., 2013). Research conducted in German Holsteins to identify regions of the genome associated with left displaced abomasum identified a similar region to the present study (Mömke et al., 2008). A region on BTA10 from 63.6 to $72.4 \mathrm{Mbp}$ was associated with left displaced abomasum, whereas several individual SNP on BTA10 were among the top 20 effects associated with ketosis herein (Table 3). Moderate genetic correlations have been previously cited between displaced abomasum and ketosis (Koeck et al., 2012; Neuenschwander et al., 2012; Parker Gaddis et al., 2014), which may indicate that this region has an effect on an underlying biological process affecting both of these health events.

Enrichment within the biological processes category of GO annotations identified several terms related to immune response. Among the 10 most significant GO terms $(P<0.05), 6$ were related to lymphocytes and T-cell development (Table 6); T cells play an integral role in cell-mediated immunity. This enrichment of immune-related processes supports previous research citing the important interactions between metabolic diseases, uterine health, and immune response in the periparturient dairy cow (Wathes et al., 2009; Esposito et al., 2014). Of additional interest may be those biological pathways that were underrepresented. Gene Ontology annotations found to be significantly $(P<0.05)$ underrepresented that may be of interest in relation to ketosis susceptibility included regulation of defense response (GO:0031347) and regulation of cellular response to stress (GO:0080135).

Immune-related processes were also identified in MeSH enrichment analyses. The top 10 most significantly enriched MeSH terms for both the "Chemical and Drugs" and "Phenomena and Processes" categories are listed in Table 7. Under the "Phenomena and Processes" category, immunologic cytotoxicity (MeSH: 
Table 6. The 10 most significantly enriched gene ontology (GO) terms under the biological processes category

\begin{tabular}{lcl}
\hline GO ID & $P$-value & Term \\
\hline GO:0002320 & 0.0007 & Lymphoid progenitor cell differentiation \\
GO:0098609 & 0.0045 & Cell-cell adhesion \\
GO:0030098 & 0.0048 & Lymphocyte differentiation \\
GO:0007219 & 0.0050 & Notch signaling pathway \\
GO:0070486 & 0.0053 & Leukocyte aggregation \\
GO:0070489 & 0.0053 & T cell aggregation \\
GO:0002360 & 0.0053 & T cell lineage commitment \\
GO:0042359 & 0.0053 & Vitamin D metabolic process \\
GO:0042771 & 0.0053 & Intrinsic apoptotic signaling pathway in response to DNA damage by p53 class mediator \\
GO:0044804 & 0.0053 & Nucleophagy \\
\hline
\end{tabular}

D003602) and cellular immunity (MeSH:D007111) were identified among the most significant enriched terms. Immunologic cytotoxicity includes cell destruction, which may be brought about by sensitized $\mathrm{T}$ lymphocytes. Cellular immunity includes immune responses mediated by antigen-sensitized $\mathrm{T}$ lymphocytes. Additional phenomena and processes identified as being overrepresented included reproduction (MeSH: D012098) and protein-restricted diet (MeSH:D018753). Terms related to immune response were also significant in the "Chemicals and Drugs" category. Among these were IL-8A receptors (MeSH:D023062), autoantigens (MeSH:D001324), and IL-1 receptors (MeSH:D017472). Cyclic GMP (MeSH:D006152) was also identified as significant in this category. Levels of cyclic GMP can increase in response to a variety of hormones such as acetylcholine, insulin, or oxytocin.

\section{CONCLUSIONS}

Incidence of ketosis in Jerseys was comparable to estimates from other dairy breed populations. Heritability estimates indicate that genetic improvement through selection is feasible. Based on the results of the genome-wide association study presented herein, ketosis resistance is a largely polygenic trait influenced by numerous regions throughout the genome. Several putatively associated genes were identified that could play a role in ketosis resistance in Jerseys; however, further research is needed to validate these associations. Enrichment analyses identified several overrepresented processes and terms related to immune function. Future research may also investigate how these regions identified in a Jersey population compare with those identified for other dairy breeds.

Table 7. The 10 most significantly enriched medical subject heading (MeSH) terms under the "Chemical and Drugs" and "Phenomena and Processes" categories

\begin{tabular}{lll}
\hline MeSH ID & $P$-value & MeSH term \\
\hline Chemicals and drugs & & \\
MeSH:D005680 & 0.0035 & Gamma-aminobutyric acid \\
MeSH:D024141 & 0.0035 & Collagen type IV \\
MeSH:D023062 & 0.0070 & Receptors, interleukin-8A \\
MeSH:D006152 & 0.0078 & Cyclic GMP \\
MeSH:D013111 & 0.0135 & Spider venoms \\
MeSH:D002786 & 0.0144 & Cholesterol side-chain cleavage enzyme \\
MeSH:D001324 & 0.0148 & Autoantigens \\
MeSH:D007202 & 0.0185 & Indicators and reagents \\
MeSH:D003012 & 0.0217 & Microbial collagenase \\
MeSH:D017472 & 0.0217 & Receptors, interleukin-1 \\
Phenomena and processes & & \\
MeSH:D053263 & 0.0029 & Gene regulatory networks \\
MeSH:D003602 & 0.0070 & Cytotoxicity, immunologic \\
MeSH:D007111 & 0.0070 & Immunity, cellular \\
MeSH:D002881 & 0.0135 & Chromosomes, Human, Pair 12 \\
MeSH:D012098 & 0.0343 & Reproduction \\
MeSH:D000917 & 0.0428 & Antibody formation \\
MeSH:D018753 & 0.0428 & Diet, protein-restricted \\
MeSH:D002872 & 0.0490 & Chromosome deletion \\
MeSH:D004306 & 0.0490 & Dose-response relationship, immunologic \\
MeSH:D014815 & 0.0490 & Vitamins \\
\hline
\end{tabular}




\section{ACKNOWLEDGMENTS}

The authors thank the dairy producers and Dairy Records Management Systems (Raleigh, NC) for providing the data. The authors also thank the American Jersey Cattle Club Research Foundation (Reynoldsburg, $\mathrm{OH}$ ) for providing funding for this study.

\section{REFERENCES}

Aguilar, I., I. Misztal, A. Legarra, and S. Tsuruta. 2011. Efficient computation of the genomic relationship matrix and other matrices used in single-step evaluation. J. Anim. Breed. Genet. 128:422428. https://doi.org/10.1111/j.1439-0388.2010.00912.x.

Aguilar, I., I. Misztal, S. Tsuruta, A. Legarra, and H. Wang. 2014. PREGSF90 - POSTGSF90: Computational tools for the implementation of single-step genomic selection and genome-wide association with ungenotyped individuals in BLUPF90 programs. In Proc. 10th World Congr. Genet. Appl. Livest. Prod., Vancouver, Canada. Am. Soc. Anim. Sci., Champaign, IL.

Ashburner, M., C. A. Ball, J. A. Blake, D. Botstein, H. Butler, J. M. Cherry, A. P. Davis, K. Dolinski, S. S. Dwight, J. T. Eppig, M. A. Harris, D. P. Hill, L. Issel-Tarver, A. Kasarskis, S. Lewis, J. C. Matese, J. E. Richardson, M. Ringwald, G. M. Rubin, and G. Sherlock. 2000. Gene Ontology: Tool for the unification of biology. Nat. Genet. 25:25-29. https://doi.org/10.1038/75556.

Baird, G. D. 1982. Primary ketosis in the high-producing dairy cow: Clinical and subclinical disorders, treatment, prevention, and outlook. J. Dairy Sci. 65:1-10. https://doi.org/10.3168/jds.S0022 $-0302(82) 82146-2$.

Bigras-Poulin, M., A. H. H. Meek, S. W. W. Martin, and I. McMillan. 1990. Health problems in selected Ontario Holstein cows: Frequency of occurrences, time to first diagnosis and associations. Prev. Vet. Med. 10:79-89. https://doi.org/10.1016/0167-5877(90)90053 $-\mathrm{K}$.

Blache, D., P. Celi, M. A. Blackberrv, R. A. Dynes, and G. B. Martin 2000. Decrease in voluntary feed intake and pulsatile luteinizing hormone secretion after intracerebroventricular infusion of recombinant bovine leptin in mature male sheep. Reprod. Fertil. Dev. 12:373-381. https://doi.org/10.1071/RD00102.

Blum, J. W., P. Kunz, H. Leuenberger, K. Gautschi, and M. Keller. 1983. Thyroid hormones, blood plasma metabolites and haematological parameters in relationship to milk yield in dairy cows. Anim. Sci. 36:93-104. https://doi.org/10.1017/S0003356100039982.

Boichard, D., and M. Brochard. 2012. New phenotypes for new breeding goals in dairy cattle. Animal 6:544-550. https://doi.org/10 $1017 /$ S1751731112000018

Buitenhuis, A. J., U. K. Sundekilde, N. A. Poulsen, H. C. Bertram, L. B. Larsen, and P. Sørensen. 2013. Estimation of genetic parameters and detection of quantitative trait loci for metabolites in Danish Holstein milk. J. Dairy Sci. 96:3285-3295. https://doi.org/ 10.3168/jds.2012-5914.

Chaudhari, A., L. Håversen, R. Mobini, L. Andersson, M. Ståhlman, E. Lu, M. Rutberg, P. Fogelstrand, K. Ekroos, A. Mardinoglu, M. Levin, R. Perkins, and J. Borén. 2016. ARAP2 promotes GLUT1mediated basal glucose uptake through regulation of sphingolipid metabolism. Biochim. Biophys. Acta Mol. Cell Biol. Lipids. 1861:1643-1651. https://doi.org/10.1016/j.bbalip.2016.07.009.

Chen, D., M. Zhao, and G. R. Mundy. 2004. Bone morphogenetic proteins. Growth Factors 22:233-241. https://doi.org/10.1080/ 08977190412331279890.

Contreras, G. A., and L. M. Sordillo. 2011. Lipid mobilization and inflammatory responses during the transition period of dairy cows. Comp. Immunol. Microbiol. Infect. Dis. 34:281-289. https://doi .org/10.1016/j.cimid.2011.01.004.

Croft, D., A. Mundo, R. Haw, M. Milacic, J. Weiser, G. Wu, M. Caudy, P. Garapati, M. Gillespie, M. R. Kamdar, B. Jassal, S. Jupe, L. Matthews, B. May, S. Palatnik, K. Rothfels, V. Shamovsky, H. Song, M. Williams, E. Birney, H. Hermjakob, L. Stein, and
P. D'Eustachio. 2014. The Reactome pathway knowledgebase. Nucleic Acids Res. 42:D472-D477. https://doi.org/10.1093/nar/ gkt1102.

Curtis, C. R., H. N. Erb, C. J. Sniffen, R. D. Smith, and D. S. Kronfeld. 1985. Path analysis of dry period nutrition, postpartum metabolic and reproductive disorders, and mastitis in Holstein cows. J. Dairy Sci. 68:2347-2360.

Dai, X. Q., G. Plummer, M. Casimir, Y. Kang, C. Hajmrle, H. Y. Gaisano, J. E. Manning Fox, and P. E. MacDonald. 2011. SUMOylation regulates insulin exocytosis downstream of secretory granule docking in rodents and humans. Diabetes 60:838-847. https://doi.org/10.2337/db10-0440.

Dantzer, R., and K. W. Kelley. 2007. Twenty years of research on cytokine-induced sickness behavior. Brain Behav. Immun. 21:153-160. https://doi.org/10.1016/j.bbi.2006.09.006.

Dohoo, I. R., and S. W. Martin. 1984. Subclinical ketosis: prevalence and associations with production and disease. Can. J. Comp. Med. $48: 1-5$.

Du, C., X. Ma, S. Meruvu, L. Hugendubler, and E. Mueller. 2014. The adipogenic transcriptional cofactor ZNF638 interacts with splicing regulators and influences alternative splicing. J. Lipid Res. 55:1886-1896. https://doi.org/10.1194/jlr.M047555.

Esposito, G., P. C. Irons, E. C. Webb, and A. Chapwanya. 2014. Interactions between negative energy balance, metabolic diseases, uterine health and immune response in transition dairy cows. Anim. Reprod. Sci. 144:60-71. https://doi.org/10.1016/j.anireprosci.2013 .11 .007 .

Fabregat, A., K. Sidiropoulos, P. Garapati, M. Gillespie, K. Hausmann, R. Haw, B. Jassal, S. Jupe, F. Korninger, S. McKay, L. Matthews, B. May, M. Milacic, K. Rothfels, V. Shamovsky, M. Webber, J. Weiser, M. Williams, G. Wu, L. Stein, H. Hermjakob, and P. D'Eustachio. 2016. The Reactome pathway Knowledgebase. Nucleic Acids Res. 44:D481-D487. https://doi.org/10.1093/nar/ gkv1351.

Falcon, S., and R. Gentleman. 2007. Using GOstats to test gene lists for GO term association. Bioinformatics 23:257-258.

Fugate, R. T., L. H. Dauten, G. R. Wiggans, and H. M. White. 2014. Determination of single nucleotide polymorphisms associated with subclinical ketosis in Jersey cattle. J. Dairy Sci. 97(E-Suppl. 1):472. (Abstr.)

Geer, L. Y., A. Marchler-Bauer, R. C. Geer, L. Han, J. He, S. He, C. Liu, W. Shi, and S. H. Bryant. 2010. The NCBI BioSystems database. Nucleic Acids Res. 38:D492-D496. https://doi.org/10 $.1093 /$ nar/gkp858.

Gordon, J. L., S. J. LeBlanc, and T. F. Duffield. 2013. Ketosis treatment in lactating dairy cattle. Vet. Clin. North Am. Food Anim. Pract. 29:433-445. https://doi.org/10.1016/j.cvfa.2013.03.001.

Goulley, J., U. Dahl, N. Baeza, Y. Mishina, and H. Edlund. 2007. BMP4-BMPR1A signaling in $\beta$ cells is required for and augments glucose-stimulated insulin secretion. Cell Metab. 5:207-219. https://doi.org/10.1016/j.cmet.2007.01.009.

Grgurevic, L., G. L. Christensen, T. J. Schulz, and S. Vukicevic. 2016 Bone morphogenetic proteins in inflammation, glucose homeostasis and adipose tissue energy metabolism. Cytokine Growth Factor Rev. 27:105-118. https://doi.org/10.1016/j.cytogfr.2015.12.009.

Gröhn, Y., J. R. Thompson, and M. L. Bruss. 1984. Epidemiology and genetic basis of ketosis in Finnish Ayrshire cattle. Prev. Vet. Med. 3:65-77.

Gröhn, Y. T., H. N. Erb, C. E. McCulloch, and H. S. Saloniemi. 1989 Epidemiology of metabolic disorders in dairy cattle: Association among host characteristics, disease, and production. J. Dairy Sci. 72:1876-1885. https://doi.org/10.3168/jds.S0022-0302(89)79306 -1 .

Gross, J., H. A. van Dorland, F. J. Schwarz, and R. M. Bruckmaier. 2011. Endocrine changes and liver mRNA abundance of somatotropic axis and insulin system constituents during negative energy balance at different stages of lactation in dairy cows. J. Dairy Sci. 94:3484-3494. https://doi.org/10.3168/jds.2011-4251.

Guo, H., J. B. Callaway, and J. P.-Y. Ting. 2015. Inflammasomes: mechanism of action, role in disease, and therapeutics. Nat. Med. 21:677-687. https://doi.org/10.1038/nm.3893. 
Henao-Mejia, J., E. Elinav, C. A. Thaiss, and R. A. Flavell. 2014. Inflammasomes and metabolic disease. Annu. Rev. Physiol. 76:5778. https://doi.org/10.1146/annurev-physiol-021113-170324.

Herdt, T. H. 2000. Ruminant adaptation to negative energy balance. Influences on the etiology of ketosis and fatty liver. Vet. Clin. North Am. Food Anim. Pract. 16:215-230. https://doi.org/10 .1016/S0749-0720(15)30102-X.

Heringstad, B., Y. M. Chang, D. Gianola, and G. Klemetsdal. 2005. Genetic analysis of clinical mastitis, milk fever, ketosis, and retained placenta in three lactations of Norwegian red cows. J. Dairy Sci. 88:3273-3281. https://doi.org/10.3168/jds.S0022 -0302(05)73010-1.

Hu, Z. L., C. A. Park, X. L. Wu, and J. M. Reecy. 2013. Animal QTLdb: An improved database tool for livestock animal QTL/association data dissemination in the post-genome era. Nucleic Acids Res. 41:D871-D879. https://doi.org/10.1093/nar/gks1150.

Ingvartsen, K. L., and Y. R. Boisclair. 2001. Leptin and the regulation of food intake, energy homeostasis and immunity with special focus on periparturient ruminants. Domest. Anim. Endocrinol. 21:215-250. https://doi.org/10.1016/S0739-7240(02)00119-4.

Isidor, B., O. Pichon, R. Redon, D. Day-Salvatore, A. Hamel, K. A. Siwicka, M. Bitner-Glindzicz, D. Heymann, L. Kjellén, C. Kraus, J. G. Leroy, G. R. Mortier, A. Rauch, A. Verloes, A. David, and C. Le Caignec. 2010. Mesomelia-synostoses syndrome results from deletion of sulf1 and slco5a1 genes at 8q13. Am. J. Hum. Genet. 87:95-100. https://doi.org/10.1016/j.ajhg.2010.05.012.

Kadarmideen, H. N., R. Thompson, G. Simm, and M. Eh. 2000. Linear and threshold model genetic parameters for disease, fertility and milk production in dairy cattle. Anim. Sci. 71:411-419.

Kanehisa, M., M. Furumichi, M. Tanabe, Y. Sato, and K. Morishima. 2017. KEGG: New perspectives on genomes, pathways, diseases and drugs. Nucleic Acids Res. 45:D353-D361. https://doi.org/10 $.1093 /$ nar/gkw1092.

Kerestes, M., V. Faigl, M. Kulcsár, O. Balogh, J. Földi, H. Fébel, Y. Chilliard, and G. Huszenicza. 2009. Periparturient insulin secretion and whole-body insulin responsiveness in dairy cows showing various forms of ketone pattern with or without puerperal metritis. Domest. Anim. Endocrinol. 37:250-261. https://doi.org/10.1016/j domaniend.2009.07.003.

Kessel, S., M. Stroehl, H. H. D. Meyer, S. Hiss, H. Sauerwein, F. J. Schwarz, and R. M. Bruckmaier. 2008. Individual variability in physiological adaptation to metabolic stress during early lactation in dairy cows kept under equal conditions. J. Anim. Sci. 86:29032912. https://doi.org/10.2527/jas.2008-1016.

Koeck, A., F. Miglior, D. F. Kelton, and F. S. Schenkel. 2012. Health recording in Canadian Holsteins: data and genetic parameters. J. Dairy Sci. 95:4099-4108. https://doi.org/10.3168/jds.2011-5127.

Lamming, D. W., and D. M. Sabatini. 2013. A central role for mTOR in lipid homeostasis. Cell Metab. 18:465-469. https://doi.org/10 .1016/j.cmet.2013.08.002

Liang, D., L. M. Arnold, C. J. Stowe, R. J. Harmon, and J. M. Bewley. 2017. Estimating US dairy clinical disease costs with a stochastic simulation model. J. Dairy Sci. 100:1472-1486. https://doi.org/10 .3168/jds.2016-11565.

Medway, C., and K. Morgan. 2014. Review: The genetics of Alzheimer's disease; putting flesh on the bones. Neuropathol. Appl. Neurobiol. 40:97-105. https://doi.org/10.1111/nan.12101.

Meruvu, S., L. Hugendubler, and E. Mueller. 2011. Regulation of adipocyte differentiation by the zinc finger protein ZNF638. J. Biol. Chem. 286:26516-26523. https://doi.org/10.1074/jbc.M110 .212506 .

Mignarri, A., A. Rubegni, A. Tessa, S. Stefanucci, A. Malandrini, E. Cardaioli, M. C. Meschini, M. L. Stromillo, S. Doccini, A. Federico, F. M. Santorelli, and M. T. Dotti. 2016. Mitochondrial dysfunction in hereditary spastic paraparesis with mutations in DDHD1/SPG28. J. Neurol. Sci. 362:287-291. https://doi.org/10 .1016 /j.jns.2016.02.007

Misztal, I., S. Tsuruta, T. Strabel, B. Auvray, T. Druet, and D. H. Lee. 2002. BLUPF90 and related programs (BGF90). Pages 1-2 in Proc. 7th World Congr. Genet. Appl. Livest. Prod., Montpellier, France. INRA, Cedex, France.
Mömke, S., H. Scholz, K. Doll, J. Rehage, and O. Distl. 2008. Mapping quantitative trait loci for left-sided displacement of the abomasum in German Holstein dairy cows. J. Dairy Sci. 91:4383-4392. https://doi.org/10.3168/jds.2008-1260.

Morota, G., F. Peñagaricano, J. L. Petersen, D. C. Ciobanu, K. Tsuyuzaki, and I. Nikaido. 2015. An application of MeSH enrichment analysis in livestock. Anim. Genet. 46:381-387.

Neuenschwander, T. F.-O., F. Miglior, J. Jamrozik, O. Berke, D. F. Kelton, and L. R. Schaeffer. 2012. Genetic parameters for producer-recorded health data in Canadian Holstein cattle. Animal 6:571-578. https://doi.org/10.1017/S1751731111002059.

O'Leary, N. A., M. W. Wright, J. R. Brister, S. Ciufo, D. Haddad, R. McVeigh, B. Rajput, B. Robbertse, B. Smith-White, D. AkoAdjei, A. Astashyn, A. Badretdin, Y. Bao, O. Blinkova, V. Brover, V. Chetvernin, J. Choi, E. Cox, O. Ermolaeva, C. M. Farrell, T. Goldfarb, T. Gupta, D. Haft, E. Hatcher, W. Hlavina, V. S. Joardar, V. K. Kodali, W. Li, D. Maglott, P. Masterson, K. M. McGarvey, M. R. Murphy, K. O'Neill, S. Pujar, S. H. Rangwala, D. Rausch, L. D. Riddick, C. Schoch, A. Shkeda, S. S. Storz, H. Sun, F. Thibaud-Nissen, I. Tolstoy, R. E. Tully, A. R. Vatsan, C. Wallin, D. Webb, W. Wu, M. J. Landrum, A. Kimchi, T. Tatusova, M. DiCuccio, P. Kitts, T. D. Murphy, and K. D. Pruitt. 2016. Reference sequence (RefSeq) database at NCBI: Current status, taxonomic expansion, and functional annotation. Nucleic Acids Res. 44:D733-D745. https://doi.org/10.1093/nar/gkv1189.

Oetzel, G. R. 2007. Herd-level ketosis-Diagnosis and risk factors. Pages 67-91 in Proc. Am. Assoc. Bov. Pract., Vancouver, BC, Canada. Am. Assoc. Bovine Pract., Opelika, AL

Ogawa, T., Y. Kawano, T. Imamura, K. Kawakita, M. Sagara, T. Matsuo, Y. Kakitsubata, T. Ishikawa, K. Kitamura, K. Hatakeyama, Y. Asada, and T. Kodama. 2010. Reciprocal contribution of pentraxin 3 and C-reactive protein to obesity and metabolic syndrome. Obesity (Silver Spring) 18:1871-1874. https://doi.org/10 .1038/oby.2009.507.

Ogorevc, J., T. Kunej, A. Razpet, and P. Dovc. 2009. Database of cattle candidate genes and genetic markers for milk production and mastitis. Anim. Genet. 40:832-851. https://doi.org/10.1111/j .1365-2052.2009.01921.x.

Papadopoulos, C., G. Orso, G. Mancuso, M. Herholz, S. Gumeni, N. Tadepalle, C. Jüngst, A. Tzschichholz, A. Schauss, S. Höning, A. Trifunovic, A. Daga, and E. I. Rugarli. 2015. Spastin binds to lipid droplets and affects lipid metabolism. PLoS Genet. 11:e1005149. https://doi.org/10.1371/journal.pgen.1005149.

Parker Gaddis, K. L., J. B. Cole, J. S. Clay, and C. Maltecca. 2012. Incidence validation and relationship analysis of producer-recorded health event data from on-farm computer systems in the United States. J. Dairy Sci. 95:5422-5435. https://doi.org/10.3168/jds .2012-5572.

Parker Gaddis, K. L., J. B. Cole, J. S. Clay, and C. Maltecca. 2014 Genomic selection for producer-recorded health event data in US dairy cattle. J. Dairy Sci. 97:3190-3199. https://doi.org/10.3168/ jds.2013-7543.

Pryce, J. E., R. J. Esslemont, R. Thompson, R. F. Veerkamp, M. A. Kossaibati, and G. Simm. 1998. Estimation of genetic parameters using health, fertility and production data from a management recording system for dairy cattle. Anim. Sci. 66:577-584. https:// doi.org/10.1017/S1357729800009152.

Pryce, J. E., K. L. Parker Gaddis, A. Koeck, C. Bastin, M. Abdelsayed, N. Gengler, F. Miglior, B. Heringstad, C. Egger-Danner, K. F. Stock, A. J. Bradley, and J. B. Cole. 2016. Invited review: Opportunities for genetic improvement of metabolic diseases. J. Dairy Sci. 99:6855-6873. https://doi.org/10.3168/jds.2016-10854.

Qian, S.-W., Y. Tang, X. Li, Y. Liu, Y.-Y. Zhang, H.-Y. Huang, R.-D. Xue, H.-Y. Yu, L. Guo, H.-D. Gao, Y. Liu, X. Sun, Y.-M. Li, W.-P. Jia, and Q.-Q. Tang. 2013. BMP4-mediated brown fat-like changes in white adipose tissue alter glucose and energy homeostasis. Proc. Natl. Acad. Sci. USA 110:E798-E807. https://doi.org/10.1073/ pnas. 1215236110.

Quinlan, A. R., and I. M. Hall. 2010. BEDTools: A flexible suite of utilities for comparing genomic features. Bioinformatics 26:841842. https://doi.org/10.1093/bioinformatics/btq033. 
R Core Team. 2017. R: A Language and Environment for Statistical Computing. R Foundation for Statistical Computing, Vienna, Austria. https://www.R-project.org/.

Sartelet, A., T. Stauber, W. Coppieters, C. F. Ludwig, C. Fasquelle, T. Druet, Z. Zhang, N. Ahariz, N. Cambisano, T. J. Jentsch, and C. Charlier. 2014. A missense mutation accelerating the gating of the lysosomal $\mathrm{Cl}-/ \mathrm{H}+-$-exchanger $\mathrm{ClC}-7 /$ Ostm1 causes osteopetrosis with gingival hamartomas in cattle. Dis. Model. Mech. 7:119-128. https://doi.org/10.1242/dmm.012500.

Suriben, R., K. A. Kaihara, M. Paolino, M. Reichelt, S. K. Kummerfeld, Z. Modrusan, D. L. Dugger, K. Newton, M. Sagolla, J. D. Webster, J. Liu, M. Hebrok, and V. M. Dixit. 2015. $\beta$-cell insulin secretion requires the ubiquitin ligase COP1. Cell 163:1457-1467. https://doi.org/10.1016/j.cell.2015.10.076.

Tetens, J., C. Heuer, I. Heyer, M. S. Klein, W. Gronwald, W. Junge, P. J. Oefner, G. Thaller, and N. Krattenmacher. 2015. Polymorphisms within the APOBR gene are highly associated with milk levels of prognostic ketosis biomarkers in dairy cows. Physiol Genomics 47:129-137. https://doi.org/10.1152/physiolgenomics .00126 .2014$.

Tetens, J., T. Seidenspinner, N. Buttchereit, and G. Thaller. 2013. Whole-genome association study for energy balance and fat/protein ratio in German Holstein bull dams. Anim. Genet. 44:1-8 https://doi.org/10.1111/j.1365-2052.2012.02357.x.

Tsuruta, S., and I. Misztal. 2006. THRGIBBS1F90 for estimation of variance components with threshold linear models. Pages 27-31 in Proc. 8th World Congr. Genet. Appl. Livest. Prod., Belo Horizonte, Brazil. Instituto Prociencia, Belo Horizonte, Brazil.

Tsuyuzaki, K., G. Morota, M. Ishii, T. Nakazato, S. Miyazaki, and I. Nikaido. 2015. MeSH ORA framework: R/Bioconductor packages to support MeSH over-representation analysis. BMC Bioinformatics 16:45 https://doi.org/10.1186/s12859-015-0453-z

Vanholder, T., J. Papen, R. Bemers, G. Vertenten, and A. C. B. C. B. Berge. 2015. Risk factors for subclinical and clinical ketosis and association with production parameters in dairy cows in the Netherlands. J. Dairy Sci. 98:880-888. https://doi.org/10.3168/ jds.2014-8362.

VanRaden, P. M., J. R. O'Connell, G. R. Wiggans, and K. A. Weigel. 2011. Genomic evaluations with many more genotypes. Genet. Sel. Evol. 43:10.

Vukasinovic, N., N. Bacciu, C. A. Przybyla, P. Boddhireddy, and S. K. DeNise. 2017. Development of genetic and genomic evaluation for wellness traits in US Holstein cows. J. Dairy Sci. 100:428-438. https://doi.org/10.3168/jds.2016-11520.

Wathes, D. C., Z. Cheng, W. Chowdhury, M. A. Fenwick, R. Fitzpatrick, D. G. Morris, J. Patton, and J. J. Murphy. 2009. Negative energy balance alters global gene expression and immune responses in the uterus of postpartum dairy cows. Physiol. Genomics 39:1-13.

Wiggans, G. R., T. Cooper, P. VanRaden, C. Van Tassell, D. Bickhart, and T. Sonstegard. 2016. Increasing the number of single nucleotide polymorphisms used in genomic evaluation of dairy cattle. J. Dairy Sci. 99:4504-4511. https://doi.org/10.3168/jds.2015-10456.

Wiggans, G. R., P. M. VanRaden, L. R. Bacheller, M. E. Tooker, J. L. Hutchison, T. A. Cooper, and T. S. Sonstegard. 2010. Selection and management of DNA markers for use in genomic evaluation. J. Dairy Sci. 93:2287-2292. https://doi.org/10.3168/jds.2009-2773.

Yang, C.-Y., J.-B. Chen, T.-F. Tsai, Y.-C. Tsai, C.-Y. Tsai, P.-H. Liang, T.-L. Hsu, C.-Y. Wu, M. G. Netea, C.-H. Wong, and S.-L. Hsieh. 2013. CLEC4F is an inducible C-type lectin in F4/80-positive cells and is involved in alpha-galactosylceramide presentation in liver. PLoS One 8:e65070 https://doi.org/10.1371/journal.pone .0065070 .

Yates, A., W. Akanni, M. R. Amode, D. Barrell, K. Billis, D. Carvalho-Silva, C. Cummins, P. Clapham, S. Fitzgerald, L. Gil, C. G. Girón, L. Gordon, T. Hourlier, S. E. Hunt, S. H. Janacek, N. Johnson, T. Juettemann, S. Keenan, I. Lavidas, F. J. Martin, T. Maurel, W. McLaren, D. N. Murphy, R. Nag, M. Nuhn, A. Parker, M. Patricio, M. Pignatelli, M. Rahtz, H. S. Riat, D. Sheppard, K. Taylor, A. Thormann, A. Vullo, S. P. Wilder, A. Zadissa, E. Birney, J. Harrow, M. Muffato, E. Perry, M. Ruffier, G. Spudich, S. J. Trevanion, F. Cunningham, B. L. Aken, D. R. Zerbino, and P. Flicek. 2016. Ensembl 2016. Nucleic Acids Res. 44:D710-D716. https://doi.org/10.1093/nar/gkv1157.

Zimin, A. V., A. L. Delcher, L. Florea, D. R. Kelley, M. C. Schatz, D. Puiu, F. Hanrahan, G. Pertea, C. P. Van Tassell, T. S. Sonstegard, G. Marçais, M. Roberts, P. Subramanian, J. A. Yorke, and S. L. Salzberg. 2009. A whole-genome assembly of the domestic cow, Bos taurus. Genome Biol. 10:R42. https://doi.org/10.1186/ gb-2009-10-4-r42.

Zwald, N. R., K. A. Weigel, Y. M. Chang, R. D. Welper, and J. S. Clay. 2004. Genetic selection for health traits using producerrecorded data. I. Incidence rates, heritability estimates, and sire breeding values. J. Dairy Sci. 87:4287-4294. 